\title{
The 3rd Canadian Symposium on Hepatitis C Virus: Expanding care in the interferon-free era
}

\author{
Sonya A MacParland PhD ${ }^{1}$, Marc Bilodeau MD², Jason Grebely $\mathrm{PhD}^{3}$, Julie Bruneau MD4, Curtis Cooper MD ${ }^{5}$, \\ Marina Klein $\mathrm{MD}^{6}$, Selena M Sagan PhD7, Norma Choucha ${ }^{2}$, Louise Balfour PhD ${ }^{5}$, Frank Bialystok PhD, \\ Mel Krajden $\mathrm{MD}^{8,9}$, Jennifer Raven $\mathrm{PhD}^{10}$, Eve Roberts $\mathrm{MD}^{1}$, Rodney Russell $\mathrm{PhD}^{11}$, \\ Michael Houghton $\mathrm{PhD}^{12}$, D Lorne Tyrrell MD PhD ${ }^{12}$, Jordan J Feld $\mathrm{MD}^{1}$; \\ on behalf of the National CIHR Research Training Program in Hepatitis C
}

\begin{abstract}
SA MacParland, M Bilodeau, J Grebely, et al. The 3rd Canadian Symposium on Hepatitis C Virus: Expanding care in the interferon-free era. Can J Gastroenterol Hepatol 2014;28(9): 481-487.
\end{abstract}

Hepatitis C virus (HCV) currently infects approximately 250,000 individuals in Canada and causes more years of life lost than any other infectious disease in the country. In August 2011, new therapies were approved by Health Canada that have achieved higher response rates among those treated, but are poorly tolerated. By 2014/2015, shortcourse, well-tolerated treatments with cure rates $>95 \%$ will be available. However, treatment uptake is poor due to structural, financial, geographical, cultural and social barriers. As such, 'Barriers to access to HCV care in Canada' is a crucial topic that must be addressed to decrease $\mathrm{HCV}$ disease burden and potentially eliminate $\mathrm{HCV}$ in Canada. Understanding how to better care for HCV-infected individuals requires integration across multiple disciplines including researchers, clinical services and policy makers to address the major populations affected by HCV including people who inject drugs, baby boomers, immigrants and Aboriginal and/or First Nations people. In 2012, the National CIHR Research Training Program in Hepatitis C organized the 1st Canadian Symposium on Hepatitis C Virus (CSHCV) in Montreal, Quebec. The 2nd CSHCV was held in 2013 in Victoria, British Columbia. Both symposia were highly successful, attracting leading international faculty with excellent attendance leading to dialogue and knowledge translation among attendees of diverse backgrounds. The current article summarizes the 3rd CSHCV, held February 2014, in Toronto, Ontario.

Key Words: Biomedical; Clinical; Epidemiology; Hepatitis C; Public health; Social sciences

\section{Le $3^{\mathrm{e}}$ symposium canadien sur le virus de l'hépatite $\mathrm{C}$ : élargir les soins en cette ère de traitement sans interféron}

Le virus de l'hépatite C (VHC), qui infecte environ 250000 personnes au Canada, est responsable de plus d'années de vie perdues que toute autre maladie infectieuse au pays. En août 2011, Santé Canada a approuvé de nouvelles thérapies, dont les taux de réponse sont plus élevés chez les patients traités, mais qui sont mal tolérées. En 20142015, des traitements de courte durée, mais bien tolérés, assurant un taux de guérison de plus de $95 \%$, seront mis en marché. Cependant, la participation au traitement est faible, en raison d'obstacles structurels, financiers, géographiques, culturels et sociaux. C'est pourquoi les obstacles à l'accès aux soins du VHC au Canada constituent un sujet essentiel, qu'il faut aborder pour réduire le fardeau du VHC et peutêtre éliminer le virus au Canada. Pour comprendre comment mieux soigner les personnes infectées par le VHC, il faut parvenir à intégrer de multiples disciplines, y compris les chercheurs, les services cliniques et les décideurs, afin de répondre aux besoins des principales populations atteintes du VHC, incluant les utilisateurs de drogues injectables, les baby-boomers, les immigrants et les personnes autochtones ou des Premières nations. En 2012, la Subvention nationale de formation des IRSC sur l'hépatite $\mathrm{C}$ a organisé le $1^{\mathrm{er}}$ symposium canadien sur le virus de l'hépatite $\mathrm{C}$ à Montréal, au Québec. Le $2^{\mathrm{e}}$ a eu lieu à Victoria, en Colombie-Britannique, en 2013. Ces deux symposiums ont obtenu un franc succès, car ils ont attiré des conférenciers internationaux réputés et suscité une excellente participation, ce qui a favorisé le dialogue et le partage de connaissances entre congressistes provenant de divers horizons. Le présent article résume le $3^{\mathrm{e}}$ symposium, qui s'est déroulé en février 2014 à Toronto, en Ontario.

population with chronic HCV treated in 2013 (1). Treatment uptake is limited by structural, financial, geographical, cultural and social barriers. In 2013, the lifetime cost for an individual infected with HCV was estimated to be $\$ 64,694$ (1). To maximize the impact of the highly effective therapies that have recently been developed, it will be critical to improve treatment access, which can only be achieved by addressing the barriers to access to HCV care in Canada, with the goal to reduce disease burden and, ultimately, eliminate HCV infection from Canada.

Extending care to $\mathrm{HCV}$-infected individuals requires a coordinated effort by clinicians, nurses, researchers and policy makers, and requires consideration of the unique needs of specific Canadian populations affected by HCV including people who inject drugs (PWID) and ever before with shortened courses of therapy. However, treatment uptake is poor across the country, with $<2 \%(n=3600)$ of the total

${ }^{1}$ University of Toronto, Toronto, Ontario; ${ }^{2}$ Liver Unit, Department of Medicine, Université de Montréal, Montréal, Québec; ${ }^{3}$ The Kirby Institute,

UNSW Australia, Sydney, Australia; ${ }^{4}$ Department of Family Medicine, Université de Montréal, Montréal, Québec; ${ }^{5}$ Division of Infectious Diseases,

University of Ottawa, Ottawa, Ontario; ${ }^{6}$ Division of Infectious Diseases; ${ }^{7}$ Department of Microbiology $\mathcal{E}$ Immunology, McGill University, Montreal,

Quebec; ${ }^{8}$ British Columbia Centre for Disease Control; ${ }^{9}$ University of British Columbia, Vancouver, British Columbia; ${ }^{10}$ Canadian Institutes of Health

Research - Institute of Infection and Immunity, Ottawa, Ontario; ${ }^{11}$ Division of Biomedical Sciences, Memorial University of Newfoundland, St John's,

Newfoundland 8 Labrador; ${ }^{12} \mathrm{Li} \mathrm{Ka}$ Shing Institute of Virology, University of Alberta, Edmonton, Alberta

Correspondence and reprints: Dr Sonya MacParland, University of Toronto, 1 Kings College Circle, Toronto, Ontario M5S 3K5.

Telephone 416-320-8339, e-mail sonyamacparland@gmail.com

Received for publication August 6, 2014. Accepted August 12, 2014 
HCV-infected Aboriginal persons, with both groups being identified by the Public Health Agency of Canada (PHAC) as being at increased risk for new HCV infections $(3,4)$. In February 2012, the Canadian Institutes of Health Research (CIHR)-based National CIHR Research Training Program in Hepatitis C (NCRTP-HepC) organized the 1st Canadian Symposium on Hepatitis C Virus (CSHCV) in Montreal, Quebec. The 2nd CSHCV was held in March 2013 in Victoria, British Columbia (5). These symposia were well attended and attracted leading international experts, leading to dialogue and knowledge translation among attendees of diverse backgrounds. The current article summarizes the 3rd CSHCV, held February 2014, in Toronto, Ontario, where new Canadian and international HCV research findings were presented. It also gives an overview of the multidisciplinary discussions centred on improving access to care for HCV-infected Canadians. Specifically discussed were the challenges of delivering care to special populations of HCV-infected persons. Also highlighted was the need for a Canadian HCV action plan that would guide the provision of prevention, care and treatment for all Canadians infected with or at risk for acquiring HCV. The absence of such a plan remains a major obstacle that limits the marshalling of resources needed for HCVinfected Canadians to benefit from these potent, curative antivirals.

\section{THE NCRTP-HepC}

The NCRTP-HepC is a CIHR-supported Strategic Training Initiative in Health Research that was first funded in 2003 (www.ncrtp-hepc. $\mathrm{ca} /$ ). The NCRTP-HepC is a partnership funded by public groups including the CIHR, PHAC and the Canadian Liver Foundation, and which receives private funding from both industry and community organizations. The main goal of the NCRTP-HepC is to build translational HCV research capacity, and to prevent, care and treat HCV with the desire to eliminate HCV disease in Canada within the next 10 to 15 years. The training program uses the knowledge of 35 leading researchers from universities across Canada, who act as mentors for the trainees and who advance Canadian HCV research. The NCRTP$\mathrm{HepC}$ is interdisciplinary, with members representing diverse research backgrounds, including social and behavioural sciences, epidemiology and public health, clinical and biomedical sciences. Since 2003, the NCRTP-HepC has supported 71 trainees (11 MSc, $35 \mathrm{PhD}$, thee MD and 22 postdoctoral) and 45 summer students. This has significantly enhanced Canadian HCV research capacity, knowledge translation and interdisciplinary collaboration.

The NCRTP-HepC is a leader in facilitating HCV research in Canada (5). In response to feedback from the 1st and 2nd CSHCV, and questionnaires completed by community groups including the Canadian Liver Foundation's 'Living with Liver Diseases' support group and the Toronto Community Hepatitis C Program, the specific aims of the 3rd CSHCV were:

1. To facilitate transdisciplinary knowledge exchange and collaborations among Canadian trainees, established researchers, health care practitioners, health policy makers and communitybased groups working in the field of HCV.

2. To discuss approaches that would lead to increased treatment uptake across the country with a focus on expanding care and access to difficult-to-reach populations with the ultimate goal of eliminating HCV in Canada.

3. To implement, plan and deliver knowledge exchange and dissemination of symposium findings to support practice change, community awareness, harm reduction and policy development.

4. To implement a long-term plan for sustaining an annual CSHCV.

\section{THE 3rd CSHCV}

Providing better care for HCV-infected individuals requires integration between researchers and policy makers across multiple disciplines. The theme of the 3rd CSHCV was "Expanding care for HCV-infected Individuals" and the program was divided into four sessions focusing on biomedical sciences, clinical sciences, social sciences, and epidemiology and public health. The primary audience included Canadian investigators, research trainees (including $\mathrm{MSc}, \mathrm{PhD}$ and postdoctoral fellows), health care practitioners, policy makers, industry representatives and members of the affected community. The sessions, summarized below, consisted of an international plenary speaker, a Canadian speaker and peer-reviewed original oral abstracts.

\section{Biomedical sciences}

Advances in drug discovery and development have led to the approval of the first generation of direct-acting antivirals (DAAs) for the treatment of HCV $(1,6)$. Triple therapy with first-generation protease inhibitors significantly improved sustained virological response rates compared with pegylated interferon (IFN) alpha-2a and ribavirin alone. However, first-generation protease inhibitors are associated with additional side effects and complicated regimens. This has made treatment more successful but more difficult than previous standard therapy with pegylated-IFN/ribavirin (6). At the end of 2013, Health Canada approved the second-wave protease inhibitor (simeprevir) and, most significantly, the first nucleotide inhibitor of the viral polymerase (sofosbuvir). These developments will pave the way for increased availability of IFN-free anti-HCV drug regimens for Canadians infected with HCV.

Although IFN will largely be replaced by IFN-free DAA oral regimens in the near future, IFN-based therapies may still have a role due to the prohibitively high cost of the new treatments. Hence, strategies to predict or enhance the success rate of IFN-based therapies will remain relevant for patient selection and, furthermore, understanding how IFN acts will still be of importance given its central role in the innate antiviral immune response. Dr Markus Heim (University Hospital Basel, Switzerland), a world leader on IFN as an antiviral, presented data from his laboratory on IFN responsiveness and discussed the future role of IFN in a world of highly effective DAAs (7). He suggested that most countries will develop algorithms to ensure that DAAs are used to treat individuals in greatest need but perhaps not all patients. If new treatments continue to be very expensive, he projected that IFN-based regimens will still have an important role, particularly for those who are likely to respond to therapy. Thus, it is critical that we gain a better understanding of why some, but not all, patients clear chronic HCV infections with IFN-based therapy.

While there have been great advances in our understanding of the innate immune response to $\mathrm{HCV}$ infection, it remains unclear why some patients have a relatively high level of baseline activation of IFN-responsive genes whereas others have minimal or no activation of these genes despite persistent HCV infection (8). The baseline expression of IFN-responsive genes is the strongest predictor of treatment outcome with IFN-based therapy (9). The gene expression pattern in a given individual is at least partially genetically determined, with strong associations with variants near the IFN lambda-3 (IFN 33 ) gene (formerly known IL-28B), as well as with the recently identified IFN $\lambda 4$ (10-15). Patients with the treatment-unfavourable variants tend to have activated IFN systems before receiving treatment and tend to be refractory to further stimulation with IFN. Overcoming IFN refractoriness by combining DAAs with IFN, using alternative dosing strategies or other IFNs, such as IFN $\lambda$, could enhance IFN responsiveness, allowing for shorter, more effective treatments that may be an acceptable alternative to cost-prohibitive IFN-free DAA regimens.

In addition to its association with treatment outcome, the IFN $\lambda 3$ polymorphism is also associated with spontaneous resolution of acute HCV infection $(15,16)$. Dr Naglaa Shoukry (Université de Montréal, Montreal, Quebec) discussed recent work that indicated increases in IFN $\lambda 3$ in plasma occurring in acute HCV infection correlated with natural killer cell markers and degranulation (17). Natural killer cellular degranulation also correlates with the magnitude of the HCVspecific $\mathrm{T}$ cell responses, suggesting crosstalk between innate and adaptive immunity in acute HCV infection (18). A pilot transcriptome analysis of peripheral blood mononuclear cells from acute HCV patients of the Montreal Acute Hepatitis C Cohort (HEPCO) using RNA sequencing will hopefully shed some light on this important interaction (17). Preliminary results indicate differential expression of 
numerous genes, many of which function in innate and adaptive immunity. A robust induction of IFN-stimulated gene expression was demonstrated during acute HCV and, surprisingly, despite spontaneous clearance of the virus, peripheral blood mononuclear cells from resolver patients continued to demonstrate altered expression of immune genes for $>1$ year after clearance. Future studies will correlate parameters of $\mathrm{HCV}$ disease progression and compare these findings with data from patients infected with other viruses, vaccine studies and in vitro models. This will provide further insight into the interplay between innate and adaptive immunity on the outcome of HCV infection.

\section{Clinical sciences}

Access to care and treatment for marginalized and remotely located patients living with HCV is a critical issue along the cascade of care. Dr Sanjeev Arora, Director of Project ECHO (Extension for Community Healthcare Outcomes) at the University of New Mexico (Albuquerque, USA), described the objectives, structure, operation, successes and obstacles encountered with this innovative program (19). The mission of Project ECHO is to develop capacity to safely and effectively treat chronic, common and complex diseases in rural and underserved areas, and to monitor the outcomes of these treatments (20). HCV lends itself well to this model of care. Expert interdisciplinary specialist teams are linked with primary care clinicians via teleECHO clinics (21). Experts comanage patient cases and impart their expertise by way of mentorship, guidance, feedback and didactic education. In the case of $\mathrm{HCV}$, primary care physicians retain responsibility for patient management, with the ultimate goal of developing independent expertise allowing them to manage future patients and become 'local experts' for their peers, thereby reducing travel costs, wait times and improving health care quality (21). HCV care and expertise has been dramatically expanded to remote regions and marginalized populations including prisoners who historically had never received HCV treatment in New Mexico. Evaluation of this care model demonstrates health care provider and patient satisfaction, as well as cure rates that are as good, if not better, than those achieved within an academic setting. This approach to HCV care appears to be ideal for Canada but will require a willingness to demonopolize specialist knowledge, and to task shift from services traditionally provided by physicians to other health care providers, as well as convincing public payers that investing in this type of care delivery system is costeffective and sustainable.

In an extension of this topic, Drs Curtis Cooper and Julie Bruneau engaged in a lively and humorous debate entitled "Treatment should be strictly delivered by specialists rather than by primary care practitioners in the community" (22). Dr Cooper was given the difficult task of representing the 'pro' side and presenting arguments in favour of specialists strictly providing HCV care (when in fact he supported a broader approach of primary care physician involvement). Quoting Hamlet as well as research on HIV and oncology care, Dr Cooper argued that specialists were more likely to initiate treatment and choose appropriate regimens when facing complex conditions. He also pointed out that general practitioners may lack training, expertise and experience to treat specific conditions for which treatment evolves rapidly, such as with HIV and cancer survivorship $(23,24)$. He suggested that, similar to HIV and cancer, HCV treatment is quite complex and management by specialists may be required.

On the 'con' side, Dr Bruneau pointed out that, to reduce HCV morbidity and mortality, we must first and foremost substantially increase treatment uptake among those who are infected. Currently, $<10 \%$ of all infected people have access to treatment (25). Conceding that patients with severe liver conditions or multiple comorbidities should be treated in specialized academic settings with skilled and experienced specialists, she stressed the importance of having primary care physicians engaged in treating HCV-infected individuals. Not only are primary care physicians qualified to treat $\mathrm{HCV}$, they can provide testing, counselling, and treat other medical conditions that often coexist with $\mathrm{HCV}$, such as addiction and psychiatric disorders, ultimately improving the overall health outcomes (21). In the end, both debaters amicably concluded that HCV treatment should be widely available to patients according to best practices via the collaboration of primary care physicians and specialists in the best-adapted environment to meet individualized needs.

In further discussion regarding access to care, there was an emphasis on the population of HIV/HCV coinfected individuals. This group is a key population in Canada at risk for accelerated disease progression, and which faces multiple barriers in access to care and successful HCV treatment. Based on information generated from the Canadian Co-Infection Cohort, Dr Marina Klein (McGill University, Montreal, Quebec) described the current characteristics of HIV/HCV coinfected individuals in Canada, as well as the modifiable risk factors and interventions that could improve health outcomes (26). From 2003 to 2013 , this population had a standardized mortality rate that was $>12$-fold that of the Canadian population (27). This is driven primarily by end-stage liver disease, drug overdose and malignancy. Use of current IFN-based HCV antiviral and HIV antiretroviral therapies reduces this risk for the individual but not at the general population level. Although HCV antiviral therapy initiation rates are higher than in other cohorts, females, Aboriginals and those with a history of crack/cocaine use were less likely to initiate treatment. HCV antiviral initiation rates differed considerably among the 18 sites contributing data to this cohort, suggesting that standardizing HCV care in coinfection should be prioritized. The value of enhanced access to HCV antiviral therapy was also discussed. Benefits include improved patient quality of life scores and reduced health care utilization following achievement of a sustained virological response. However, the multiple socioeconomic barriers faced by the HIV-HCV coinfected population will need to be addressed to ensure maximum benefit.

\section{Social and behavioral sciences}

In Canada, the majority of new and existing cases of HCV occur among PWID, either currently or in the past $(1,28)$. Dr Jason Grebely (University of New South Wales, Australia), discussed a communitybased study of PWID in Vancouver (British Columbia) documenting that HCV treatment uptake was only 2\% per year in 2010 (29), despite universal access to health care. Treatment among PWID has added benefits, including the potential to reduce HCV transmission. Treatment as prevention has the potential to markedly reduce incidence and, ultimately, prevalence across the country $(25,30)$. Clearly, strategies are needed to enhance HCV treatment uptake, particularly among PWID.

Barriers to HCV treatment are multifactorial and include issues of access to therapy and barriers at the level of the patient, practitioner and the health care system (31-33). Dr Carla Treloar (University of New South Wales, Australia), explored how stigma, social exclusion, symbolic violence and trust could be better understood and used to develop more effective therapeutic encounters to address barriers to HCV care, particularly among PWID (34). Drawing from social theory and research from a number of qualitative studies with clients and practitioners (35-39), she suggested some pragmatic strategies of how practitioners could develop inclusive, nondiscriminatory, trust-building HCV services to enhance HCV assessment and treatment.

In addition to enhancing engagement to HCV care and treatment, strategies to enhance responses to HCV therapy are also needed. Dr Louise Balfour (University of Ottawa, Ottawa, Ontario), highlighted the importance of adherence to HCV therapy (40). Specifically, Dr Balfour emphasized the important role that psychologists can play in helping to address barriers to care at the level of the patient, and helping to better prepare HCV patients for therapy, which may lead to improved adherence and, ultimately, improved outcomes in HCV therapy (41). Adherence will be particularly important with the new oral DAA regimens given the very high costs of failed therapy. Adherence strategies are particularly important for PWID or individuals with serious mental health issues (42). 


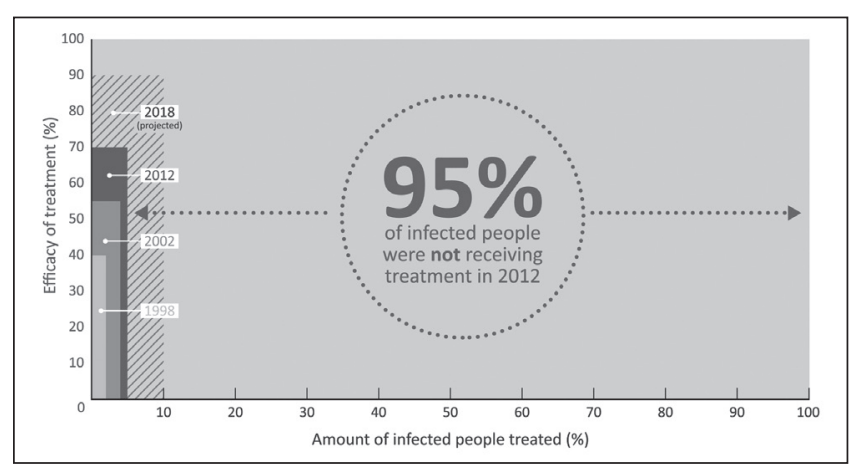

Figure 1) The disparity between potential hepatitis $\mathrm{C}$ virus (HCV) treatment efficacy and projected HCV treatment effectiveness. High efficacy of HCV treatment is projected over five to 10 years. Sustained virological response (SVR) has increased from 40\% with interferon (IFN) and ribavirin (RBV) in 1998, 55\% with pegylated-IFN (PEG-IFN) and RBV in 2002, approximately $70 \%$ in the era of PEG-IFN, RBV, and a protease inhibitor in 2012 (genotype 1 only; patients with HCV genotype 2 or 3 will still have an SVR of approximately $80 \%$ with PEG-IFN-RBV) and IFNfree regimens are anticipated to be available by 2018, with an expected SVR of $90 \%$. However, the global effects of new treatments are negligible without expanded access given the low treatment uptake among individuals with HCV infection (57-59). Reproduced with permission from reference 25

One collaborative community-based group model of care that has been incredibly successful for treating a highly marginalized population was presented by Dr Jeff Powis from the Toronto Community Hep C program (43). This model has demonstrated that PWID can be engaged in HCV treatment (44) and treatment responses resemble those observed in clinical trials, despite the presence of multiple comorbidities $(44,45)$.

The impressive advances in the development of DAA-based therapy, particularly IFN-free regimens, provide the potential to cure HCV infection in the vast majority of treated individuals. However, as shown in Figure 1, there is a considerable disparity between the potential treatment efficacy $(>90 \%)$ and the current HCV treatment effectiveness $(<10 \%)$, given that $<10 \%$ of people have been treated in most countries, including Canada. Unless the proportion of individuals screened, assessed and treated for HCV infection is substantially increased, these anticipated therapeutic advances will have limited impact at the population level (46).

\section{Epidemiology and public health}

More than one-half of all existing HCV infections are estimated to be in current or former PWID $(2,25)$. HCV treatment uptake in this population is low overall, and is especially low among current PWID (47-49). Barriers to HCV treatment are multifactorial and include issues of access to therapy and barriers at the level of the patient, practitioner and the health care system (25). Active drug use and mental health problems are often key factors affecting HCV treatment decision by both patients and providers (25). Some of these barriers are associated with medication side effects, factors that affect therapy adherence and concerns regarding reinfection. However, there is ample evidence that, with appropriate care and support, PWID can be effectively treated for HCV, with international guidelines recommending HCV treatment for PWID on a case-by-case basis $(25,50)$. Dr Kim Page (University of San Francisco, California, USA), discussed HCV 'treatment cascade' in PWID and individuals with substance use and mental health issues, how these issues impact care delivery and reviewed strategies that may impact successful delivery of care in this population (51). She spoke of the 'incredible shrinking patient'. After clinicians apply a series of criteria to exclude patients (eg, AUDIT score for alcohol use, depression scores, laboratory criteria and active injection drug use) as few as $4 \%$ of patients are deemed eligible for current HCV treatments. Dr Page described the UFO "You Find Out" study, which provides an opportunity for PWID younger than 30 years of age in San Francisco to undergo testing and learn if they are infected with HCV or HIV. The UFO model was presented as an example of a successful HCV education and prevention program, demonstrating how integration of harm reduction, outreach, testing, education and onsite primary care can engage and care for young injection drug users.

Another significant at-risk population with a high prevalence of HCV and low treatment uptake is the First Nations community (52). Dr Kathy Pouteau (Family Physician, Sioux Lookout and Kasabonika Lake First Nation, Ontario) shared her experiences and model for delivering HCV prevention and care to a remote Aboriginal community in Northern Ontario (53). First Nations communities in Northwestern Ontario have seen markedly increased rates of HCV infection. Risk factors for infection include injection drug use and, in 2009, the Chiefs of the Nishnawbe Aski Nation declared a state of emergency around prescription drug use in their communities. Dr Pouteau discussed the challenges, opportunities and collaborative response of health service providers and First Nations in rural and remote communities in the Sioux Lookout area. Barriers to HCV prevention, diagnosis and care in these communities include fragmented primary and public health systems, limited access to harm reduction programs, difficulties in confirming HCV diagnosis and accessing posttest counselling, limited access to HCV support and treatment, barriers due to intergenerational and personal trauma as well as ongoing inequities in social, economic and political determinants of health. These barriers are being addressed by health care providers in First Nations communities using a collaborative approach. This approach centres around five main priorities: building political advocacy and support; encouraging communication and collaboration with health services agencies; establishing meaningful partnerships based in First Nations communities (ie, opioid substitution programs); building First Nations HCV capacity, local 'expert' resources and tertiary partnerships; and promoting culturally safe and trusting relationships between health care providers and community members.

A critical player in the national response to $\mathrm{HCV}$ is PHAC. One of the challenges facing policy makers is the limitations in the comprehensiveness of HCV surveillance data in Canada, which makes it highly challenging to estimate the HCV disease burden. Dr Maxim Troubnikov from PHAC presented an updated model for determining estimates of the prevalent and undiagnosed HCV infections in Canada in 2011 (54). This model followed approaches used by the Center for Communicable Diseases and Infection Control (CCDIC) to estimate the $2011 \mathrm{HCV}$ disease burden using the workbook and the back-calculation modelling methods. Using the workbook method, preliminary results, based on a Canadian population of $34,483,975$, estimated that the anti- $\mathrm{HCV}^{+}$prevalence for 2011 was $0.96 \%(95 \%$ CI 0.61 to 1.34 ), corresponding to 331,046 persons (95\% CI 210,352 to 462,085 persons), while the chronic $\mathrm{HCV}$ prevalence was $0.71 \%$ (95\% CI $0.45 \%$ to $0.99 \%$ ), corresponding to 244,836 persons ( $95 \%$ CI 155,177 to 341,391 persons). It was further estimated that $44 \%$ of anti-HCV-positive persons were likely undiagnosed in 2011, although before having a final estimate, input from the back-calculation process and validation is required.

The second PHAC presentation, by Dr Margaret Gale-Rowe of the CCDIC, outlined the actions and the current federal response to HCV prevention and control (55). The current PHAC response includes HCV research collaboration and support, active disease surveillance and epidemiology, as well as the development of professional guidelines and resources for the management of HCV (56). Workshops and studies held by PHAC over the past year include discussion of birth cohort screening for $\mathrm{HCV}$, a topic that was debated in the 2nd CSHCV (5). As a result, there is an interim statement that is under development on HCV screening based on the birth cohort approach in addition to current risk-based screening. Programs and partnerships 
that PHAC has fostered include promoting public and professional awareness campaigns including World Hepatitis Day and funding for the expansion of HCV knowledge including funding for the NCRTPHepC and the Global Hepatitis C Technical Network. The current PHAC response to HCV was outlined and presently exists as part of an integrated response to sexually transmitted and blood borne infections including HIV, HCV and other infections. In the discussion period following these presentations, there was discussion about the need for a unified national strategy for hepatitis $\mathrm{C}$ in Canada. Although the PHAC representatives acknowledged the value of such an approach, no concrete plans to develop a national strategy currently exist.

\section{OUTCOMES OF THE 3rd CSHCV}

Although current treatments for HCV are effective, the severe side effect profile, prolonged duration, need for specialized support and the high cost, greatly limit treatment uptake. By 2014/2015, it is likely that all-oral, well-tolerated HCV treatment will be available with cure rates $>95 \%$ in treated individuals. These new treatments will dramatically improve the ability to initiate treatment and cure those infected. However, translating these remarkable therapeutic improvements into tangible reductions in disease morbidity and mortality will require significant improvements in treatment uptake. With this in mind, the major focus on HCV in Canada will likely shift from the drug discovery to developing strategies to engage people into care and treatment. The 3rd CSHCV highlighted strategies that have proven effective in increasing treatment uptake internationally and nationally, with a focus on practical implementation of successful approaches in Canada.

The challenges of increasing HCV treatment uptake in Canada are structural, financial, geographical, cultural and social. It is time to develop achievable goals of treating the four major population groups in Canada that are most affected - PWID, baby boomers, immigrants and Aboriginal/First Nations people - so that HCV in Canada can be eliminated within the next 10 to 15 years. Among those at risk, PWID will require a specific focus for harm reduction to prevent reinfection. Without a screening program to identify those who remain undiagnosed, disease elimination will not be achieved. It will be critical to confirm whether the preliminary PHAC estimate that $44 \%$ of Canadians are unaware of their infection is correct. The key topic of discussion at this symposium was whether HCV care should be strictly provided by subspecialist clinicians or whether primary care physicians should treat HCV-infected individuals. The issues raised were the complexity of HCV treatment regimens in addition to the fact that, if all HCV-infected individuals were to be treated, there would not be a sufficient number of subspecialists to fill the need. The broad consensus was that a blended model of care, including many health care disciplines, will be required to maximize identification, treatment initiation and HCV cure. The notion of employing the ECHO model of telemedicine to reach geographically isolated areas was presented, a model that has been especially effective in providing HCV care in remote areas of the United States (21).

This symposium highlighted that given the unique challenges of the HCV epidemic and the imminent potential for curability, there is a clear need for national coordination of $\mathrm{HCV}$ prevention, care and treatment. National strategies have been adopted in countries, such as Australia, Scotland and the United States, which have resulted in improvements in HCV prevention, care and treatment (5). Canada needs a national strategy or action plan so that Canadians can also benefit from the imminent curability of HCV so that disease elimination within the next 10 to 15 years can become a realized dream.

ACKNOWLEDGEMENTS: National CIHR Research Training Program in Hepatitis C (NCRTP-HepC) Mentors - Marc Bilodeau (Program Director, Université de Montréal), Norma Choucha (Program Administrator, CRCHUM), Louise Balfour (University of Ottawa), Julie Bruneau (Université de Montréal), Gail Butt (University of British Columbia), Brian Conway (Vancouver Infectious Diseases Centre), Curtis Cooper (University of Ottawa), Aled Edwards (University of Toronto),
Jordan Feld (University of Toronto), Benedikt Fischer (Simon Fraser University), Matthias Götte (McGill University), Jason Grebely (University of New South Wales), Michael Houghton (University of Alberta), Marina Klein (McGill University), Norman Kneteman (University of Alberta), Murray Krahn (University of Toronto), Mel Krajden (University of British Columbia), Gary Levy (University of Toronto), Qiang Liu (University of Saskatchewan), Ian McGilvray (University of Toronto), Thomas Michalak (Memorial University), Gerry Mugford (Memorial University), Rob Myers (University of Calgary), Mario Ostrowski (University of Toronto), Arnim Pause (McGill University), John Pezacki (University of Ottawa), Chris Richardson (Dalhousie University), Eve Roberts (University of Toronto), Rod Russell (Memorial University), Luis Schang (University of Alberta), Naglaa Shoukry (Université de Montréal), Nahum Sonenberg (McGill University), Hugo Soudeyns (Université de Montréal), Raymond Tellier (University of Toronto), Mark Tyndall (University of Ottawa), D Lorne Tyrrell (University of Alberta), and Joyce Wilson (University of Saskatchewan). Postdoctoral Trainees - Maude Boisvert (Université de Montréal), Marion Depla (Université de Montréal), Benoît Dupont (Université de Montréal), Maryam Ehteshami (Emory University), Moheshwarnath Issur (McGill University), Sonya MacParland (University of Toronto), Andrea Olmstead (University of British Columbia), Mohamed Sarhan (University of Alberta), Rick Siu (Dalhousie University) Nick van Buuren (Stanford University). PhD Trainees - Christopher Ablenas (McGill University), Annie Bernier (McGill University), Evan Cunningham (University of New South Wales), Thomas Fabre (Université de Montréal), Ahmed Fahmy (Université de Québec), Brett Hoffman (University of Saskatchewan), Anastasia Hyrina (University of British Columbia), Hassan Kofahi (Memorial University), Anupriya Kulkarni (McGill University), Nasheed Moqueet (McGill University), Neda Nasheri Ardakan (University of Ottawa), Ragunath Singaravelu (University of Ottawa), Patricia Thibault (University of Saskatchewan), Qi Wu (University of Saskatchewan). MSc Trainees - Adelina Artenie (McGill University), Svetlana Puzhko (McGill University), Sahar Saeed (McGill University), Nathan Taylor (Memorial University), Jason Wong (University of Alberta). Lay members - Frank Bialystok (University of Toronto), Andrew Cumming.

FUNDING: The NCRTP-HepC is funded by a Training Grant from the Canadian Institutes of Health Research (CIHR, grant number 63298). In addition, the NCRTP-HepC receives funding from AbbVie, Boehringer Ingelheim, Bristol Myers Squibb Canada Co., the Canadian Liver Foundation, Gilead, Merck, Novartis, Roche and Vertex. The 1st CSHCV (Grant number 264748), the 2nd CSHCV (grant number 290924) and the 3rd CSHCV (Grant number 309251) were supported by the CIHR. Additional funding for the 3rd CSHCV was provided by: AbbVie, Boehringer-Ingelheim, Bristol-Myers Squibb, Gilead, Janssen, Merck, Novartis, Roche and Vertex. SM is supported through a CIHR postdoctoral fellowship and was an NCRTP-HepC postdoctoral trainee. JG is supported through a National Health and Medical Research Council Career Development Fellowship. SMS was an Amgen Fellow of the Life Sciences Research Foundation (LSRF) and was an NCRTP-HepC postdoctoral trainee. The views expressed in this publication are those of the author(s) and do not reflect the position of the CIHR or PHAC.

\section{REFERENCES}

1. Myers RP, Krajden M, Bilodeau M, et al. Burden of disease and cost of chronic hepatitis C infection in Canada. Can J Gastroenterol Hepatol 2014:28:243-50.

2. Hajarizadeh B, Grebely J, Dore GJ. Epidemiology and natural history of HCV infection. Nat Rev Gastroenterol Hepatol 2013;10:553-62.

3. PHAC. Public Health Agency of Canada: Hepatitis C in Canada: 2005-2010 surveillance report. 2012. <www.phac-aspc.gc.ca/sti-itssurvepi/hepc/surv-eng.php> (Accessed June 5, 2014).

4. Dinner K DT, Potts J, Sirna J, Wong T. Hepatitis C: A public health perspective and related implications for physicians. Royal College Outlook 2005;2:20-22.

5. Grebely J, Bilodeau M, Feld JJ, et al. The Second Canadian Symposium on Hepatitis C Virus: A call to action. Can J Gastroenterol 2013;27:627-32. 
6. Muir AJ. The rapid evolution of treatment strategies for hepatitis C. Am J Gastroenterol 2014;109:628-35.

7. Heim M. The Role of the Innate Immune Response in HCV in the Era of Interferon-free Therapy. 3rd Canadian Symposium on Hepatitis C Virus Infection. Toronto, February 7, 2014:10. <www. ncrtp-hepc.ca/images/documents/Symposium2014/2014_01_23_ symposium_program_and_abstract_book_final.pdf $>$ (Accessed September 12, 2014).

8. Wieland S, Makowska Z, Campana B, et al. Simultaneous detection of hepatitis $\mathrm{C}$ virus and interferon stimulated gene expression in infected human liver. Hepatology 2014;59:2121-30.

9. McGilvray I, Feld JJ, Chen LM, et al. Hepatic cell-type specific gene expression better predicts HCV treatment outcome than IL28B genotype. Gastroenterology 2012;142:1122-31.

10. Ge D, Fellay J, Thompson AJ, et al. Genetic variation in IL28B predicts hepatitis $\mathrm{C}$ treatment-induced viral clearance. Nature 2009;461:399-401.

11. Rauch A, Kutalik Z, Descombes P, et al. Genetic variation in IL28B is associated with chronic hepatitis $\mathrm{C}$ and treatment failure: A genome-wide association study. Gastroenterology 2010;138:1338-45,45:e1-7.

12. Suppiah V, Moldovan M, Ahlenstiel G, et al. IL28B is associated with response to chronic hepatitis $\mathrm{C}$ interferon-alpha and ribavirin therapy. Nat Genet 2009;41:1100-4.

13. Tanaka Y, Nishida N, Sugiyama M, et al. Genome-wide association of IL28B with response to pegylated interferon-alpha and ribavirin therapy for chronic hepatitis C. Nat Genet 2009;41:1105-9.

14. Bibert S, Roger T, Calandra T, et al. IL28B expression depends on a novel TT/-G polymorphism which improves HCV clearance prediction. J Exp Med 2013;210:1109-16.

15. Prokunina-Olsson L, Muchmore B, Tang W, et al. A variant upstream of IFNL3 (IL28B) creating a new interferon gene IFNL4 is associated with impaired clearance of hepatitis $C$ virus. Nat Genet 2013;45:164-71.

16. Thomas DL, Thio CL, Martin MP, et al. Genetic variation in IL28B and spontaneous clearance of hepatitis $\mathrm{C}$ virus. Nature 2009;461:798-801.

17. Shoukry N. Immune signatures during acute HCV. 3rd Canadian Symposium on Hepatitis C Virus Infection. Toronto, February 7, 2014:11. <www.ncrtp-hepc.ca/images/documents/ Symposium2014/2014_01_23_symposium_program_and_abstract_ book_final.pdf> (Accessed September 12, 2014).

18. Pelletier S, Drouin C, Bedard N, Khakoo SI, Bruneau J, Shoukry NH. Increased degranulation of natural killer cells during acute $\mathrm{HCV}$ correlates with the magnitude of virus-specific $\mathrm{T}$ cell responses. J Hepatol 2010;53:805-16.

19. Arora S. Project ECHO: A Model to Improve Care in Canada. 3rd Canadian Symposium on Hepatitis C Virus Infection. Toronto, February 7, 2014:8. <www.ncrtp-hepc.ca/images/documents/ Symposium2014/2014_01_23_symposium_program_and_abstract_ book_final.pdf> (Accessed September 12, 2014).

20. Arora S, Geppert CMA, Kalishman S, et al. Academic Health Center management of chronic diseases through knowledge networks: Project ECHO. Acad Med 2007;82:154-60.

21. Arora S, Kalishman S, Thornton K, et al. Expanding Access to Hepatitis C Virus Treatment-Extension for Community Healthcare Outcomes (ECHO) Project: Disruptive innovation in specialty care. Hepatology 2010;52:1124-33.

22. Bruneau J, Cooper C. Debate: Treatment should be strictly delivered by specialists rather than by primary care practitioners in the community. 3rd Canadian Symposium on Hepatitis C Virus Infection. Toronto, February 7, 2014:18. <www.ncrtp-hepc.ca/ images/documents/Symposium2014/2014_01_23_symposium_ program_and_abstract_book_final.pdf> (Accessed September 12, 2014).

23. Bober SL, Recklitis CJ, Campbell EG, et al. Caring for cancer survivors: A survey of primary care physicians. Cancer 2009;115:4409-18.

24. Kitahata MM, Koepsell TD, Deyo RA, Maxwell CL, Dodge WT, Wagner EH. Physicians' experience with the acquired immunodeficiency syndrome as a factor in patients' survival. N Engl J Med 1996;334:701-6.

25. Grebely J, Dore GJ. Can hepatitis C virus infection be eradicated in people who inject drugs? Antiviral Res 2014;104:62-72.

26. Klein MB, Rollet KC, Saeed S, et al. HIV and hepatitis C virus coinfection in Canada: Challenges and opportunities for reducing preventable morbidity and mortality. HIV Med 2013;14:10-20.
27. Klein M. The Canadian Co-infection Cohort Study: Building the Case for Increased Access to HCV Therapy for HIV-HCV Co-Infected Persons. 3rd Canadian Symposium on Hepatitis C Virus Infection. Toronto, February 7, 2014:9. <www.ncrtp-hepc.ca/ images/documents/Symposium2014/2014_01_23_symposium_ program_and_abstract_book_final.pdf> (Accessed September 12, 2014).

28. Remis R. Modelling the incidence and prevalence of hepatitis C infection and its sequelae in Canada, 2007. Final Report. Ottawa: Health Canada.

29. Alavi M, Raffa JD, Deans GD, et al. Continued low uptake of treatment for $\mathrm{HCV}$ in a large community-based cohort of inner city residents. J Hepatol 2013;58:S319-S20.

30. Grebely J, Matthews GV, Lloyd AR, Dore GJ. Elimination of hepatitis $\mathrm{C}$ virus infection among people who inject drugs through treatment as prevention: Feasibility and future requirements. Clin Infect Dis 2013;57:1014-20.

31. Grebely J, de Vlaming S, Duncan F, Viljoen M, Conway B. Current approaches to HCV infection in current and former injection drug users. J Addict Dis 2008 2008;27:25-35.

32. Grebely J, Oser M, Taylor LE, Dore GJ. Breaking down the barriers to hepatitis $\mathrm{C}$ virus (HCV) treatment among individuals with HCV/HIV coinfection: Action required at the system, provider, and patient levels. J Infect Dis 2013;207:S19-S25.

33. Grebely J, Tyndall MW. Management of HCV and HIV infections among people who inject drugs. Curr Opin HIV AIDS 2011;6:501-7.

34. Treloar C. Social issues in HCV. 3rd Canadian Symposium on Hepatitis C Virus Infection. Toronto, February 7, 2014:12.<www. ncrtp-hepc.ca/images/documents/Symposium2014/2014_01_23_ symposium_program_and_abstract_book_final.pdf $>$ (Accessed September 12, 2014).

35. Hopwood M, Treloar C, Bryant J. Hepatitis C and injecting-related discrimination in New South Wales, Australia. Drugs Educ Prev Policy 2006;13:61-75.

36. Rance J, Treloar C, ETHOS Study Group. 'Not just Methadone Tracy': Transformations in service-user identity following the introduction of hepatitis $\mathrm{C}$ treatment into Australian opiate substitution settings. Addiction 2014;109:452-9.

37. Treloar C, Rance J; on behalf of the ESG. How to build trustworthy hepatitis $\mathrm{C}$ services in an opioid treatment clinic? A qualitative study of clients and health workers in a co-located setting. Int J Drug Policy 2014;26:00014-0.

38. Treloar C, Newland J, Rance J, Hopwood M. Uptake and delivery of hepatitis $\mathrm{C}$ treatment in opiate substitution treatment: Perceptions of clients and health professionals. J Viral Hepat 2010;17:839-44.

39. Treloar C, Rance J, Grebely J, Dore GJ, ETHOS Study Group. Client and staff experiences of a co-located service for hepatitis $\mathrm{C}$ care in opioid substitution treatment settings in New South Wales, Australia. Drug Alcohol Dep 2013;133:529-34.

40. Lo Re V III, Teal V, Localio AR, Amorosa VK, Kaplan DE, Gross R. Relationship between adherence to hepatitis $\mathrm{C}$ virus therapy and virologic outcomes. Ann Internal Med 2011;155:353-46.

41. Balfour L. Bio-psycho-social framework for HCV care. 3rd Canadian Symposium on Hepatitis C Virus Infection. Toronto, February 7, 2014:13. <www.ncrtp-hepc.ca/images/documents/ Symposium2014/2014_01_23_symposium_program_and_abstract_ book_final.pdf $>$ (Accessed September 12, 2014).

42. Mathes T, Antoine S-L, Pieper D. Factors influencing adherence in hepatitis-C infected patients: A systematic review. BMC Infect Dis 2014;14.

43. Powis J. Treating the "difficult to treat": A prospective evaluation of a community-based collaborative care, group support model of HCV treatment and education. 3rd Canadian Symposium on Hepatitis C Virus Infection. Toronto, February 7, 2014:25. <www.ncrtp-hepc. ca/images/documents/Symposium2014/2014_01_23_symposium program_and_abstract_book_final.pdf $>$ (Accessed September $1 \overline{2}$, 2014).

44. Charlebois A, Lee L, Cooper E, Mason K, Powis J. Factors associated with HCV antiviral treatment uptake among participants of a community-based HCV programme for marginalized patients. J Viral Hepat 2012;19:836-42.

45. Sockalingam S, Blank D, Banga CA, Mason K, Dodd Z, Powis J. A novel program for treating patients with trimorbidity: Hepatitis C, serious mental illness, and active substance use. Eur J Gastroenterol Hepatol 2013;25:1377-84. 
46. Dore GJ. The changing therapeutic landscape for hepatitis C. Med J Australia 2012;196:629-32.

47. Grebely J, Raffa JD, Lai C, et al. Low uptake of treatment for hepatitis $\mathrm{C}$ virus infection in a large community-based study of inner city residents. J Viral Hepat 2009;16:352-8.

48. Mehta SH, Genberg BL, Astemborski J, et al. Limited uptake of hepatitis $\mathrm{C}$ treatment among injection drug users. J Commun Health 2008;33:126-33.

49. Iversen J, Grebely J, Topp L, Wand H, Dore G, Maher L. Uptake of hepatitis $\mathrm{C}$ treatment among people who inject drugs attending needle and syringe programs in Australia, 1999-2011. J Viral Hepat 2014;21:198-207.

50. Robaeys G, Grebely J, Mauss S, et al. Recommendations for the management of hepatitis $\mathrm{C}$ virus infection among people who inject drugs. Clin Infect Dis 2013;57:S129-S37.

51. Page K. Delivering Care to PWID \& Those with Substance/Mental Health Issues. 3rd Canadian Symposium on Hepatitis C Virus Infection. Toronto, February 7, 2014:16. <www.ncrtp-hepc.ca/ images/documents/Symposium2014/2014_01_23_symposium_ program_and_abstract_book_final.pdf> (Accessed September 12, 2014).

52. PHAC. Summary: Estimates of HIV Prevalence and Incidence in Canada, 2011. 2012 <www.phac-aspc.gc.ca/aids-sida/publication/ index-eng.php\# $\#>$ (Accessed June 25, 2014).

53. Pouteau K. Barriers to HCV Care for Remote First Nations in North Western Ontario. 3rd Canadian Symposium on Hepatitis C Virus Infection. Toronto, February 7, 2014:17. <www.ncrtp-hepc.ca/images/ documents/Symposium2014/2014_01_23_symposium_program_and_ abstract_book_final.pdf> (Accessed September 12, 2014).
54. Troubnikov M. Developing Estimates of the Prevalent and Undiagnosed HCV Infections in Canada in 2011. 3rd Canadian Symposium on Hepatitis C Virus Infection. Toronto, February 7, 2014:14. <www.ncrtp-hepc.ca/images/documents/ Symposium2014/2014_01_23_symposium_program_and_abstract_ book_final.pdf> (Accessed September 12, 2014).

55. Gale-Rowe M. The Public Health Agency of Canada Actions in Hepatitis C Prevention and Control. 3rd Canadian Symposium on Hepatitis C Virus Infection. Toronto, February 7, 2014:15. <www. ncrtp-hepc.ca/images/documents/Symposium2014/2014_01_23_ symposium_program_and_abstract_book_final.pdf $>$ (Accessed September 12, 2014).

56. Pinette GD CJ, Heathcote J, Moore L, Adamowski K, Riehl G. Primary Care Management of Chronic Hepatitis C - Professional Desk Reference 2009.

57. NCHECR. Epidemiological and economic impact of potential increased hepatitis $\mathrm{C}$ treatment uptake in Australia: National Centre in HIV Epidemiology and Clinical Research, The University of New South Wales, 2010.

58. Lettmeier B, Muehlberger N, Schwarzer R, et al. Market uptake of new antiviral drugs for the treatment of hepatitis C. J Hepatol 2008;49:528-36.

59. Volk ML, Tocco R, Saini S, Lok AS. Public health impact of antiviral therapy for hepatitis $C$ in the United States. Hepatology 2009;50:1750-5. 


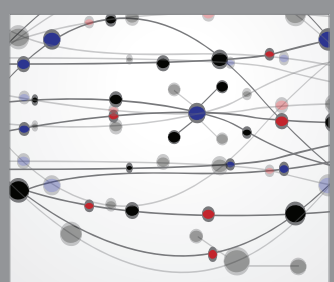

The Scientific World Journal
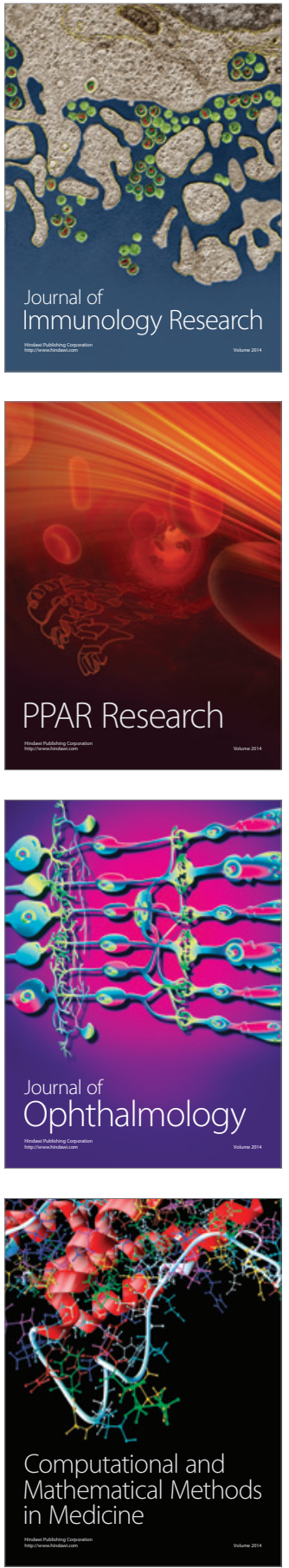

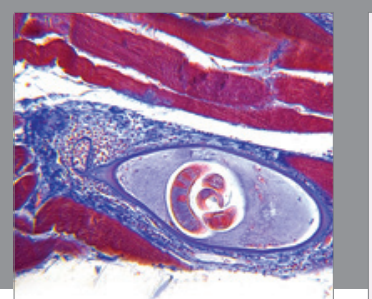

Gastroenterology Research and Practice

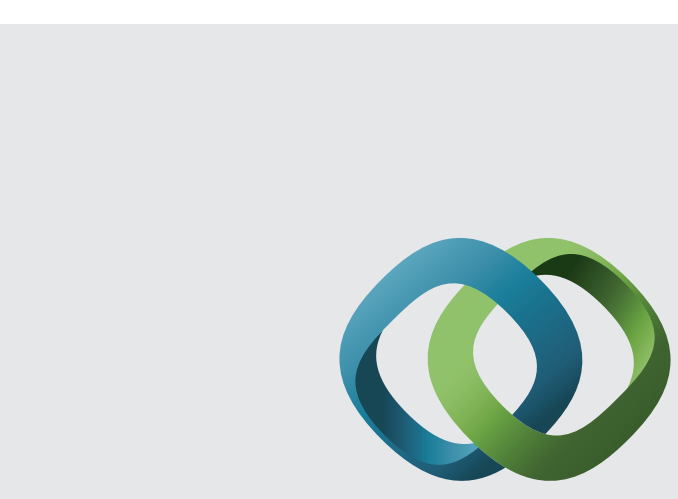

\section{Hindawi}

Submit your manuscripts at

http://www.hindawi.com
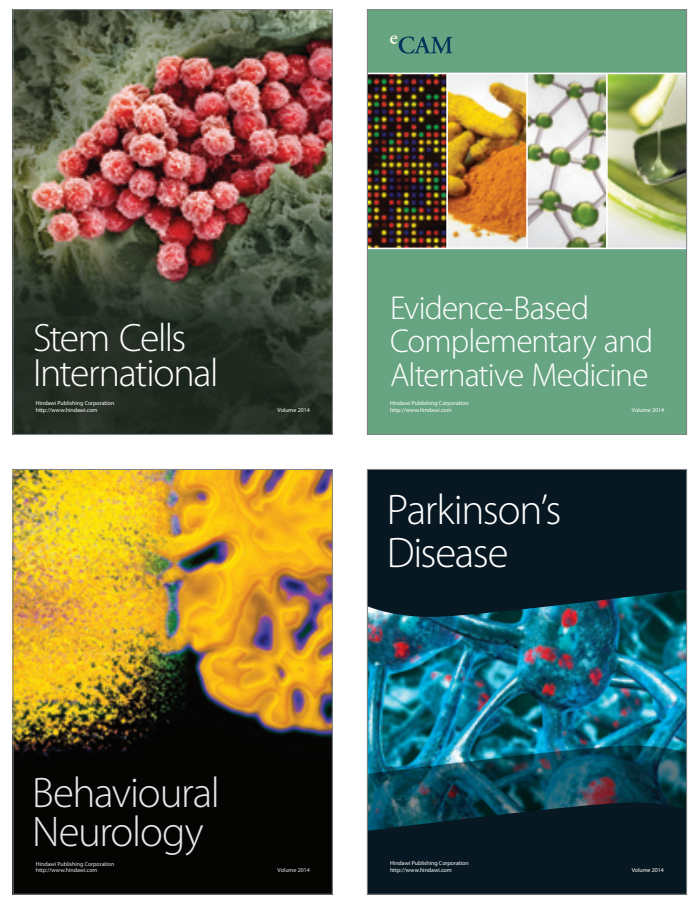
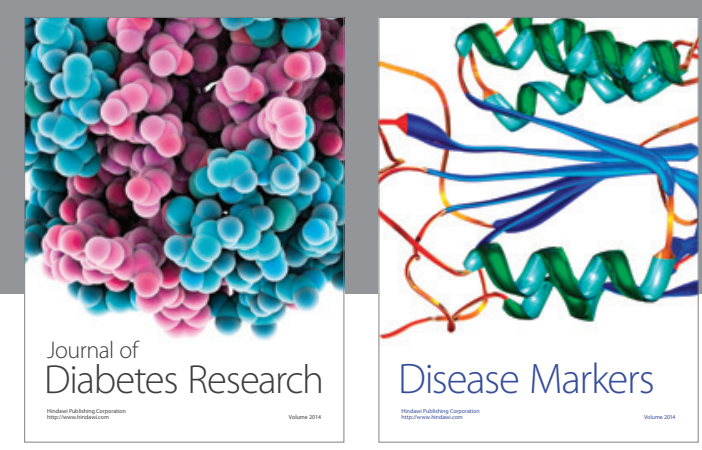

Disease Markers
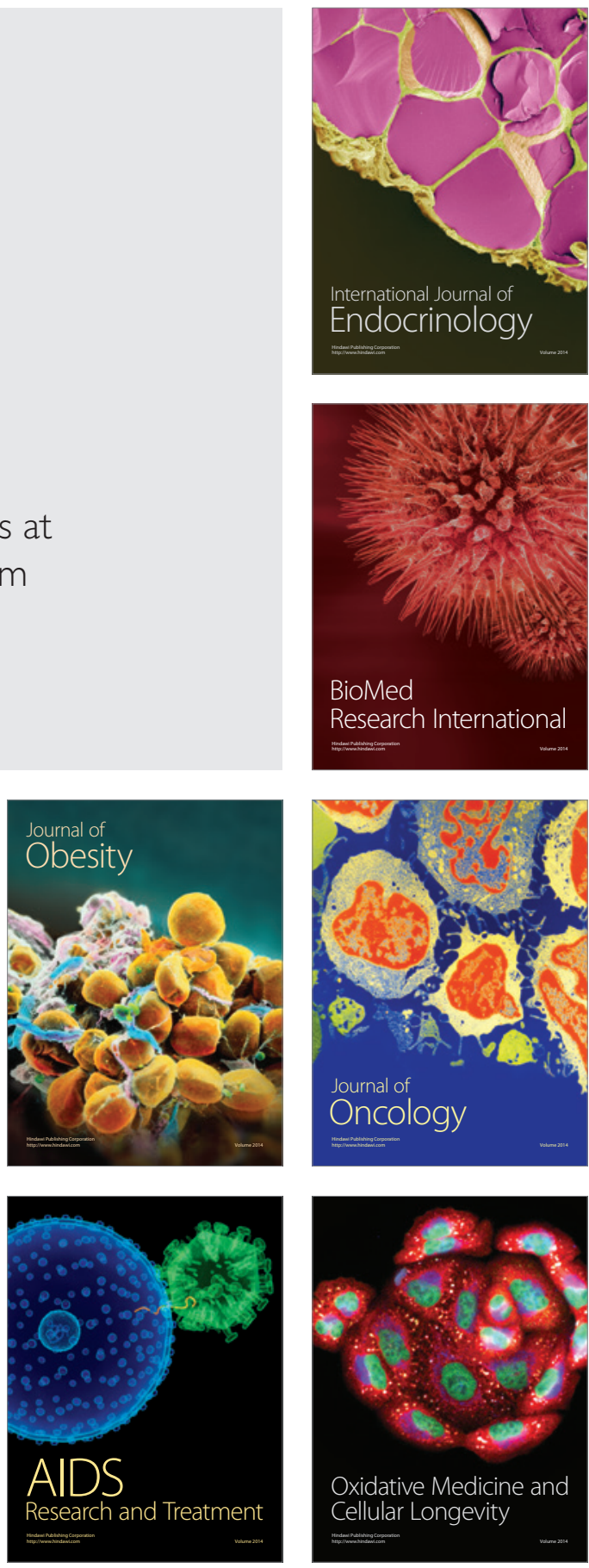